\title{
Psychiatric nursing and mental health teaching in relation to Brazilian curriculum
}

\author{
Ensino de Enfermagem Psiquiátrica e Saúde Mental face aos currículos brasileiros \\ Enseñanza de la enfermería psiquiátrica y salud mental frente a los currículos brasileños
}

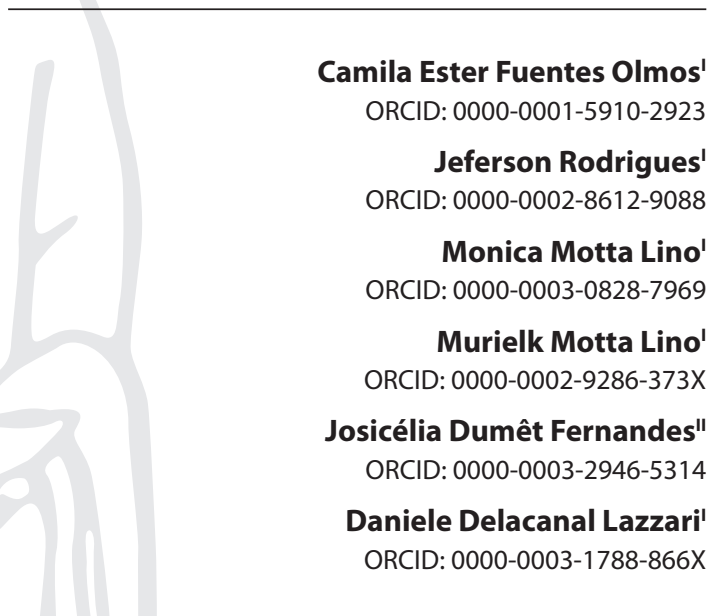

'Universidade Federal de Santa Catarina. Florianópolis, Santa Catarina, Brazil.

"Universidade Federal da Bahia. Salvador, Bahia, Brazil.

How to cite this article:

Olmos CEF, Rodrigues J, Lino MM, Lino MM, Fernandes JD, Lazzari DD. Psychiatric nursing and mental health teaching in relation to Brazilian curriculum.

Rev Bras Enferm. 2020;73(2):e20180200. doi: http://dx.doi.org/10.1590/0034-7167-2018-0200

\section{Corresponding Author:}

Camila Ester Fuentes Olmos

E-mail: eu.camila.f@hotmail.com

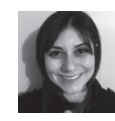

EDITOR IN CHIEF: Dulce Aparecida Barbosa ASSOCIATE EDITOR: Priscilla Broca

Submission: 03-21-2018

Approval: 11-10-2018

\begin{abstract}
Objectives: to know the scientific production on psychiatric nursing and mental health teaching in relation to Brazilian nursing curriculum. Methods: an Integrative Literature Review with no temporal delineation, whose data collection took place in ten Brazilian and international databases, adding to the total 35 objects of analysis. Results: a priori categories were adopted, consisting of the psychiatric nursing and mental health teaching in Brazil according to the 1923, 1949, 1962, 1972, 1994 and 2001 nursing curriculum, presented in the light of the dimensions: thought model; places of practice; methods or contents used; and profile or skills of the student. Final considerations: the study made it possible to observe psychiatric nursing and mental health teaching historical evolution, indicating that teaching transformations involved changes in curriculum, Psychiatric Reform and the way nursing undergraduate courses and schools take these determinants. Descriptors: Education Nursing; Psychiatric Nursing; Curriculum; Mental Health; Education, Higher.
\end{abstract}

\section{RESUMO}

Objetivos: conhecer a produção científica sobre o ensino de Enfermagem Psiquiátrica e Saúde Mental face aos currículos brasileiros de enfermagem. Métodos: Revisão Integrativa de Literatura sem delineamento temporal, cuja coleta de dados ocorreu em dez bases de dados nacionais e internacionais, somando-se ao total 35 objetos de análise. Resultados: adotaram-se categorias apriorísticas, consistindo no ensino de Enfermagem Psiquiátrica e Saúde Mental no Brasil conforme os currículos de enfermagem dos anos de 1923, 1949, 1962, 1972, 1994 e 2001, apresentados à luz das dimensões: modelo de pensamento; locais de prática; métodos ou conteúdos utilizados; e, perfil ou competências do discente. Considerações finais: o estudo possibilitou observar a evolução histórica do ensino de Enfermagem Psiquiátrica e Saúde Mental, indicando que as transformações do ensino envolveram mudanças curriculares, na Reforma Psiquiátrica e no modo como os cursos e escolas de graduação em Enfermagem se apropriam destes determinantes.

Descritores: Educação em Enfermagem; Enfermagem Psiquiátrica; Currículo; Saúde Mental; Educação Superior.

\section{RESUMEN}

Objetivos: conocer la producción científica sobre la enseñanza de la enfermería psiquiátrica y salud mental en relación con los currículos de enfermería brasileños. Métodos: Revisión Integrativa de la Literatura sin delimitación temporal, cuya recolección de datos se realizó en diez bases de datos nacionales e internacionales, sumando al total de 35 objetos de análisis. Resultados: se adoptaron categorías a priori, que consistían en la enseñanza de la enfermería psiquiátrica y salud mental en Brasil de acuerdo con los programas de enfermería de los años 1923, 1949, 1962, 1972, 1994 y 2001, presentados a la luz de las dimensiones: modelo de pensamiento; lugares de práctica; Métodos o contenidos utilizados; y perfil o habilidades del alumno. Consideraciones finales: el estudio permitió observar la evolución histórica de la enseñanza de la salud mental y la enfermería psiquiátrica, lo que indica que las transformaciones de la enseñanza implican cambios curriculares, la Reforma Psiquiátrica y la forma en que los cursos y escuelas de enfermería de pregrado toman estos determinantes.

Descriptores: Educación en Enfermería; Enfermería Psiquiátrica; Curriculum; Salud Mental; Educación Superior. 


\section{INTRODUCTION}

The understanding of any area of knowledge is related to the social, political, economic, cultural structures that underpinned its origins. It is sought, in the historical trajectory of nursing in Brazil, explanations and facts that guide the understanding of the development of psychiatric nursing and mental health teaching in schools and nursing undergraduate courses from their published curriculum bases, in which transformations arise from the legal context of education. The years 1923, 1949, 1962, 1972, 1994 and 2001 were institutional frameworks of nursing curriculum in Brazil. It is necessary to systematize such occurrences in teaching the specific area to understand the current reality ${ }^{(1)}$.

Establishment of a teaching model that effectively integrates mental health in a generalist perspective is currently a challenge in nurses'training. Psychiatric nursing and mental health teaching in Brazil follows continuous changes, reflecting the Psychiatric Reform processes, Mental Health Care Models and Curriculum Reforms. However, there is still a gap between teaching and practice of mental health nursing care, whose difficulty in defining nurses' work in this field has its possible solution in the clarification of competencies and skills essential to practice(2).

Thus, there are few scientific productions that indicate the relationship between nursing curriculum and psychiatric nursing and mental health teaching in Brazil. In view of this, the following research question was elaborated: how is the scientific production on psychiatric nursing and mental health teaching presented in relation to Brazilian nursing curriculum?

\section{OBJECTIVES}

To know the scientific production on psychiatric nursing and mental health teaching in relation to Brazilian nursing curriculum.

\section{METHODS}

\section{Type of study}

This is an Integrative Literature Review (RIL) with a qualitative, descriptive and exploratory approach. Six steps were taken: research question selection; inclusion criteria definition and sample selection; representation of selected studies in tables; critical analysis of results; discussion and interpretation of results; presentation of the evidence found $d^{(3)}$.

\section{Methodological procedures}

The databases used were Academic Search Premier; Academic Google; Cumulative Index to Nursing and Allied Health Literature ${ }^{\circ}(\mathrm{CINAHL})$; Web of Science ${ }^{\circ}$; International Literature in Health Sciences ${ }^{\circ}$ (MEDLINE); Virtual Health Library" (BIREME); Mary Ann Liebert ${ }^{\circ}$; Springer Link ${ }^{\circ}$; SciVerse Scopus ${ }^{\circ}$ and Education Resources Information Center (ERIC). They are bases that have a wide-ranging collection in health or education.

Full-text articles were included in Portuguese, Spanish and English, available through the CAPES (Coordenação de Aperfeiçoamento de Pessoal de Nível Superior - Coordination for the
Improvement of Higher Level Personnel) Journal Portal. Duplicate production was excluded or did not correspond to the research scope. Considering the analysis importance of the first scientific productions on psychiatric nursing and mental health teaching, non-delineation in the search of studies was chosen, that is, the "time" field was free.

\section{Collection and organization of data}

The search terms used in Portuguese were: Enfermagem, Ensino, Educação, Educação em Enfermagem, Enfermagem Psiquiátrica, Saúde Mental, Escolas de Enfermagem, Reforma Curricular, Graduação, Currículo and Brasil, as well as their equivalents in English and Spanish, combined as follows: (Nursing OR"Nursing Education" OR"Nursing Schools") AND ("Mental Health"OR "Psychiatric Nursing") AND ("Curriculum Reform"OR Curriculum ORTeaching OR Education OR Graduation) AND ("Brazil"), located in any part of the text corpus. Two stages of screens for filtrating the studies performed: $1^{\text {st }}$ screen: titles and abstracts were read, and those that were interpreted that the material did not correspond to the research scope were eliminated. It was observed that these studies contained keywords, but only approached studies subject. Mary Ann Liebert ${ }^{\circ}$ and Springer Link ${ }^{\circ}$ had all the studies eliminated on this screen; $2^{\text {nd }}$ screen: all the studies were read in full, and deletions occurred as the material was interpreted as not corresponding to the research scope.

\section{Data analysis}

Thematic analysis ${ }^{(4)}$ was followed, which comprises three stages of operationalization: $1^{\text {st }}$ Pre-analysis, $2^{\text {nd }}$ Material exploitation and $3^{\text {rd }}$ Results treatment and interpretation. Title, year of publication, complete reference, abstract prepared by author, keywords or descriptors, objectives, methodology, main results, textual clipping and the curriculum year commented or current were extracted from studies and recorded in tables.

An aprioristic categorization was adopted for analysis, namely: psychiatric nursing and mental health teaching in Brazil in the 1923 curriculum; psychiatric nursing and mental health teaching in Brazil in the 1949 curriculum; psychiatric nursing and mental health teaching in Brazil in the 1962 curriculum; psychiatric nursing and mental health teaching in Brazil in the 1972 curriculum; psychiatric nursing and mental health teaching in Brazil in the 1994 curriculum; and psychiatric nursing and mental health teaching in Brazil in the 2001 curriculum.

\section{RESULTS}

The initial result is exposed in each set of database, obtaining a total of 1,764 articles. Duplicates were eliminated, leaving 1,581 studies. At the end of eliminations of the first screen, 157 studies remained; and with the second screen, there were 35 objects of analysis. Results distribution by publication time is: in the $1960 \mathrm{~s}$ (1), 1980s (3), 1990s (3); from 2000 to 2011 (18); in 2012 (3); 2013 (2) and 2014 (5). Of the 35 articles selected, five of them were products of the same main author. The articles under analysis are presented with the corresponding title and purpose of the study. 
Chart 1 - Results obtained in Integrative Literature Review by title and objective

\begin{tabular}{|c|c|}
\hline Title & Objective \\
\hline $\begin{array}{l}\text { Saberes e fazeres que integram } \\
\text { o ensino de enfermagem } \\
\text { psiquiátrica na perspectiva de } \\
\text { enfermeiros docentes }{ }^{(5)}\end{array}$ & $\begin{array}{l}\text { To understand care technologies and } \\
\text { inclusion that professors use for the } \\
\text { teaching of care in freedom, from the } \\
\text { perspective of the Brazilian Psychiatric } \\
\text { Reform. }\end{array}$ \\
\hline $\begin{array}{l}\text { (Trans)formando e ousando } \\
\text { o método de ensino de } \\
\text { enfermagem no cuidado à } \\
\left.\text { saúde mental( }{ }^{6}\right)\end{array}$ & $\begin{array}{l}\text { To reflexively socialize the teaching } \\
\text { method of nursing in the mental } \\
\text { health care experienced by the } \\
\text { teaching-student group, based on } \\
\text { the (trans) formation logic of the } \\
\text { psychosocial paradigm. }\end{array}$ \\
\hline $\begin{array}{l}\text { Formação e desenvolvimento } \\
\text { de competências de estudantes } \\
\text { de enfermagem em contexto de } \\
\text { ensino clínico em saúde mental } \\
\text { e psiquiatria }{ }^{(7)}\end{array}$ & $\begin{array}{l}\text { To know the students' perspectives } \\
\text { on clinical teaching in the context } \\
\text { of psychiatry nursing and mental } \\
\text { health and the competences } \\
\text { developed in its course. }\end{array}$ \\
\hline $\begin{array}{l}\text { Mental health in primary } \\
\text { attention: needed constitution } \\
\text { of competences }{ }^{(8)}\end{array}$ & $\begin{array}{l}\text { To reflect on the need to constitute } \\
\text { new knowledge/practices for mental } \\
\text { health care in primary care, from the } \\
\text { perspective of competence. }\end{array}$ \\
\hline $\begin{array}{l}\text { A New Psychiatric Nursing in } \\
\text { the University of Brazil in the } \\
60 \text { 's of the 20th Century }\end{array}$ & $\begin{array}{l}\text { To analyze the strategies adopted in } \\
\text { Nursing Reform. }\end{array}$ \\
\hline $\begin{array}{l}\text { Discussing the education- } \\
\text { learning process in nursing } \\
\text { graduation related to mental } \\
\text { health }^{(10)}\end{array}$ & $\begin{array}{l}\text { To problematize the training of } \\
\text { mental health undergraduate } \\
\text { students. }\end{array}$ \\
\hline $\begin{array}{l}\text { Interdisciplinarity as requisite for } \\
\text { the formation of the psychiatric } \\
\text { nurse in the perspective of } \\
\text { psycho-social care }{ }^{(11)}\end{array}$ & $\begin{array}{l}\text { To analyze interdisciplinarity as } \\
\text { a fundamental element for the } \\
\text { training of the psychiatric nurse in } \\
\text { the perspective of psychosocial care. }\end{array}$ \\
\hline $\begin{array}{l}\text { Psychiatric nursing education at } \\
\text { Public Universities in the State of } \\
\text { Rio de Janeiro(12) }\end{array}$ & $\begin{array}{l}\text { To analyze programs of the disciplines } \\
\text { of psychiatric nursing and mental } \\
\text { health of nursing undergraduate } \\
\text { courses of public universities of the } \\
\text { State of Rio de Janeiro, in the light of } \\
\text { the Psychiatric Reform. }\end{array}$ \\
\hline $\begin{array}{l}\text { A brief history of psychiatric } \\
\text { nursing teaching in Brazil }{ }^{(13)}\end{array}$ & $\begin{array}{l}\text { To present a synthesis about } \\
\text { psychiatric nursing and mental } \\
\text { health teaching in Brazil. }\end{array}$ \\
\hline $\begin{array}{l}\text { Formação de Enfermeiros } \\
\text { na perspectiva da Reforma } \\
\text { Psiquiátrica(14) }\end{array}$ & $\begin{array}{l}\text { To understand which conceptions of } \\
\text { health-mental illness should guide } \\
\text { the work process of the current } \\
\text { nursing undergraduates. }\end{array}$ \\
\hline $\begin{array}{l}\text { Nursing graduation: learning } \\
\text { how to learn the brazilian } \\
\text { psychiatric reform } \\
(15)\end{array}$ & $\begin{array}{l}\text { To identify the changes incorporated } \\
\text { in undergraduate teaching in } \\
\text { psychiatric nursing. }\end{array}$ \\
\hline $\begin{array}{l}\text { Enfermagem psiquiátrica como } \\
\text { disciplina de graduação em } \\
\text { enfermagem no Brasil: uma } \\
\text { visão de conjunto }{ }^{(16)}\end{array}$ & $\begin{array}{l}\text { Historical retrospective of the } \\
\text { teaching of Psychiatric Nursing in } \\
\text { Brazil. }\end{array}$ \\
\hline $\begin{array}{l}\text { Plano de ensino para a disciplina } \\
\text { de enfermagem } \text { psiquiátrica }^{(17)}\end{array}$ & $\begin{array}{l}\text { To present a course plan for } \\
\text { Psychiatric Nursing. }\end{array}$ \\
\hline $\begin{array}{l}\text { The teaching of mental health } \\
\text { in a nursing undergraduate } \\
\text { curse: a case study }{ }^{(18)}\end{array}$ & $\begin{array}{l}\text { To describe how mental health } \\
\text { education develops in a nursing } \\
\text { undergraduate course and to verify } \\
\text { how mental health education } \\
\text { influences the training of students. }\end{array}$ \\
\hline $\begin{array}{l}\text { Teaching nursing care } \\
\text { in mental health in } \\
\text { undergraduate nursing } \\
\text { (19) }^{(19}\end{array}$ & $\begin{array}{l}\text { To analyze the teaching of nursing } \\
\text { care in mental health in the contents } \\
\text { of Pedagogical Projects and Teaching } \\
\text { Plans of Nursing Undergraduate } \\
\text { Courses of Santa Catarina between } \\
2009 \text { and } 2010 \text {. }\end{array}$ \\
\hline
\end{tabular}

Chart 1

\begin{tabular}{|c|c|}
\hline Title & Objective \\
\hline $\begin{array}{l}\text { Ensino de relacionamento } \\
\text { terapêutico em enfermagem } \\
\text { psiquiátrica: dificuldades e } \\
\text { perspectivas }^{(20)}\end{array}$ & $\begin{array}{l}\text { To disclose the attempt to adapt } \\
\text { the principles of therapeutic } \\
\text { relationship to specific issues } \\
\text { of the reality of nursing care to } \\
\text { hospitalized psychiatric patients. }\end{array}$ \\
\hline $\begin{array}{l}\text { Assistência Psiquiátrica Através } \\
\text { da Divisão de Saúde Mental eo } \\
\text { Ensino Prático de Enfermagem } \\
\text { Psiquiátrica } \\
\end{array}$ & $\begin{array}{l}\text { To describe how psychiatric care } \\
\text { occurs through the division of } \\
\text { mental health and the practical } \\
\text { teaching of psychiatric nursing. }\end{array}$ \\
\hline $\begin{array}{l}\text { The constitution of } \\
\text { competences in mental } \\
\text { health nursing education and } \\
\text { practice }^{(22)}\end{array}$ & $\begin{array}{l}\text { To analyze the representation of } \\
\text { the subjects of the research on } \\
\text { competence in mental health. }\end{array}$ \\
\hline $\begin{array}{l}\text { Teaching mental health } \\
\text { nursing care through the } \\
\text { faculty's discourse }{ }^{(23)}\end{array}$ & $\begin{array}{l}\text { To investigate how the teaching } \\
\text { of nursing care in mental health } \\
\text { materializes in the discourses of } \\
\text { psychiatric nursing and/or mental } \\
\text { health professors in the four oldest } \\
\text { nursing undergraduate courses in } \\
\text { the State of Santa Catarina. }\end{array}$ \\
\hline $\begin{array}{l}\text { Participating in the } \\
\text { construction of a teaching } \\
\text { project for nursing }{ }^{(24)}\end{array}$ & $\begin{array}{l}\text { To report the experience lived by } \\
\text { the authors as participants in the } \\
\text { process of construction of the } \\
\text { pedagogical project of the Nursing } \\
\text { Course of Universidade Federal de } \\
\text { São Carlos. }\end{array}$ \\
\hline $\begin{array}{l}\text { Integrative review about the } \\
\text { teaching of the nursing care in } \\
\text { mental health(25) }\end{array}$ & $\begin{array}{l}\text { To review the productions about } \\
\text { teaching nursing care in mental } \\
\text { health. }\end{array}$ \\
\hline $\begin{array}{l}\text { Nursing students and mental } \\
\text { health education in primary } \\
\text { care }^{(26)}\end{array}$ & $\begin{array}{l}\text { To identify how care for people with } \\
\text { mental illness was performed by } 20 \\
\text { undergraduate students in nursing } \\
\text { in the context of basic care. }\end{array}$ \\
\hline $\begin{array}{l}\text { Teaching psychiatric nursing/ } \\
\text { mental health: its interface } \\
\text { with the Brazilian Psychiatric } \\
\text { Reform and national } \\
\text { curriculum guidelines }^{(27)}\end{array}$ & $\begin{array}{l}\text { To discuss pedagogical doing in } \\
\text { psychiatric nursing and mental } \\
\text { health teaching, and its interface } \\
\text { with the principles of Psychiatric } \\
\text { Reform and the National Curricular } \\
\text { Guidelines of Undergraduate } \\
\text { Nursing Courses. }\end{array}$ \\
\hline $\begin{array}{l}\text { The Psychiatric Nursing, ABEn } \\
\text { and the Scientific Department } \\
\text { of Psychiatric and Mental } \\
\text { Health Nursing: progress and } \\
\text { challenges }^{(28)}\end{array}$ & $\begin{array}{l}\text { To contextualize Psychiatric } \\
\text { Nursing and Mental Health in Brazil, } \\
\text { considering the main historical, } \\
\text { political and social milestones that } \\
\text { influence Nursing care in this area. }\end{array}$ \\
\hline $\begin{array}{l}\text { Psychiatric nursing and } \\
\text { modern nursing in the federal } \\
\text { state of Rio de Janeiro: a lesson } \\
\text { from history }\end{array}$ & $\begin{array}{l}\text { To present the difficulties in spite of } \\
\text { the institutionalization of Nursing } \\
\text { in a Psychiatric Hospital of Rio de } \\
\text { Janeiro. }\end{array}$ \\
\hline $\begin{array}{l}\text { The conceptions and scenarios } \\
\text { of the teaching of psychiatric } \\
\text { nursing and mental health }\end{array}$ & $\begin{array}{l}\text { To address the contradictions that } \\
\text { permeate the psychiatric nursing and } \\
\text { mental health teaching in four public } \\
\text { universities in Rio Grande do Sul. }\end{array}$ \\
\hline $\begin{array}{l}\text { Oensino de enfermagem } \\
\text { psiquiátrica e saúde mental: um } \\
\text { olhar a partir das disciplinas }{ }^{(31)}\end{array}$ & $\begin{array}{l}\text { To characterize the psychiatric } \\
\text { nursing and mental health teaching } \\
\text { undergraduate courses in nursing of } \\
\text { the public universities of Rio Grande } \\
\text { do Sul rescuing their specificities. }\end{array}$ \\
\hline $\begin{array}{l}\text { Therapeutic relationship and } \\
\text { teaching of mental health } \\
\text { psychiatric nursing: tendencies } \\
\text { in the state of São Paulo }\end{array}$ & $\begin{array}{l}\text { To present a panorama on the } \\
\text { insertion of the theme of the } \\
\text { therapeutic relationship and } \\
\text { therapeutic communication in } \\
\text { nursing undergraduate teaching. }\end{array}$ \\
\hline $\begin{array}{l}\text { An object study about } \\
\text { psychiatric nursing and } \\
\text { mental health teaching } \\
\text { (33) }\end{array}$ & $\begin{array}{l}\text { To present a way to construct a } \\
\text { study object about psychiatric } \\
\text { nursing and mental health teaching. }\end{array}$ \\
\hline
\end{tabular}


Chart 1 (concluded)

\begin{tabular}{|l|l|}
\hline Title & Objective \\
\hline $\begin{array}{l}\text { The teaching of psychiatric } \\
\text { nursing and mental health } \\
\text { in the curriculum by } \\
\text { competence }\end{array}$ & $\begin{array}{l}\text { Identify if the nurse trained in } \\
\text { FAMEMA has theoretical knowledge } \\
\text { to develop the nursing tasks } \\
\text { assigned to the multidisciplinary } \\
\text { team of the Psychosocial Care } \\
\text { Centers (CAPS - Centros de Atenção } \\
\text { Psicossocial). }\end{array}$ \\
\hline $\begin{array}{l}\text { O ensino de enfermagem } \\
\text { psiquiátrica no Ceará: } a \\
\text { realidade que se esboça(3) }\end{array}$ & $\begin{array}{l}\text { To characterize and analyze } \\
\text { critically the current teaching of the } \\
\text { psychiatric nursing discipline and } \\
\text { the Psychiatric Reform project. }\end{array}$ \\
\hline $\begin{array}{l}\text { Mental health in the integrated } \\
\text { curriculum of UNIFESO's } \\
\text { nursing graduation course: } \\
\text { diversification of settings and } \\
\text { learning strategies }\end{array}$ & $\begin{array}{l}\text { To present the pedagogical } \\
\text { development for the construction } \\
\text { of competences related to mental } \\
\text { health care in the integrated } \\
\text { curriculum, implemented in the } \\
\text { Undergraduate Nursing Course of } \\
\text { UNIFESO since 2007. }\end{array}$ \\
\hline $\begin{array}{l}\text { Análise histórica das práticas } \\
\text { de enfermagem na assistência } \\
\text { psiquiátrica no Brasil, no } \\
\text { período compreendido entre as } \\
\text { décadas de 20 e 50 } 0^{(37)}\end{array}$ & $\begin{array}{l}\text { To reconstruct historically the } \\
\text { formation of nursing knowledge and } \\
\text { practices in Brazil developed in the } \\
\text { field of psychiatric care in the period } \\
\text { between the decades of 20 and 50. }\end{array}$ \\
\hline $\begin{array}{l}\text { Time: an issue in teaching } \\
\text { psychiatric nursing }\end{array}$ & $\begin{array}{l}\text { To make theoretical articulations } \\
\text { about the teaching of psychiatric } \\
\text { nursing and its particularities. }\end{array}$ \\
\hline $\begin{array}{l}\text { Psychiatric Nursing and } \\
\text { Mental Health Education in } \\
\text { University of Goiás - Brazil }{ }^{(39)}\end{array}$ & $\begin{array}{l}\text { To describe the experience of the } \\
\text { teaching of Psychiatric Nursing } \\
\text { and Mental Health at the Faculty } \\
\text { of Nursing, Universidade Federal de } \\
\text { Goiás. }\end{array}$ \\
\hline
\end{tabular}

The term "psychiatric nursing" was found in 19 titles and the term "teaching" in 23 titles. The term "curriculum" has been found three times, one of them in the "curriculum" variant. The term "Curriculum Reform"/"Curriculum Reforms" appeared in five studies, and the term "mental health" was cited in 19 titles. Overall objectives were found explicitly in 29 studies. It is emphasized that no article establishes as an object Curriculum Reform/Curriculum Reforms in the formulation of its research objectives. Regarding the method, the qualitative approach accompanies 33 articles. Methods such as integrative review (1), case study (1), theoretical reflection (9), historical studies (4) and experience report (2) were found.

The result found contains aspects related to teaching. Within this theme, the articles studied bring from the understanding of how it is structured to the new ways and possibilities of doing the psychiatric nursing and mental health teaching, mainly from the point of view of the student. Other results addressed the skills and abilities that should be expected of the student. These researches have found new ways of thinking about teaching, seeking answers that value the professor's point of view. As for the nursing curriculum themselves, those of the years 1923 and 1949 are referenced in 14 articles; that of 1962 is quoted in 11 articles; the one of 1972 quoted in 16 articles; and the 1994 curriculum is cited in 13 articles.

\section{DISCUSSION}

The discussion in each category occurred from the dimensions: thought model; places of practice; methods or contents used; and profile or expected competencies of the student.

\section{Psychiatric nursing and mental health teaching: the 1923 curriculum}

The curriculum established in 1923 in the Nursing School of the Brazilian National Department of Public Health (DNSP - Departamento Nacional de Saúde Pública), for being a pioneer, became a reference for the other Nursing teaching institutions that emerged in the early twentieth century. It is observed that the emergence of the aforementioned school represents the first institutionalization framework of nursing education in Brazil. Parallel to this consideration, studies believe that this teaching was established under the influence of American nursing, receiving a conformation that descends of the model constructed by Florence Nightingale, in $21^{\text {st }}$ century ${ }^{(10,12-13,28,37)}$.

At the time, education was based on political and economic interests, considering the United States' claim to establish as authority and reference over other countries. American nurses were sent to Brazil in order to train new nurses and reports drawn up by the latter that there were, from a foreign point of view, great gaps and difficulties in the selection of those who would be responsible for care ${ }^{(12-13)}$. Thus, modern nursing was instituted within a model of thought strongly influenced by positivist ideals, constituting as a new science. This rescue is of great value when questioning the reason that, at the beginning of the teaching, Psychiatric Nursing coexists in a marginalized way to the recognized teaching, because how the nursing care would be constituted in a scientific and rational way within a context where the hand of would care to watch, control, and punish ${ }^{(38)}$ ?

As for the places of practice and the methods or contents used, there is little discussion about the teaching of psychiatric nursing in this period. Practical classes took place in hospices ${ }^{(28-29,37-39)}$ or did not exist until $1942^{(9,29,35)}$. These divergences in nursing education are evident in the analysis of the contents offered. No records were found on pedagogical methodologies used in the period. Apparently, at that time, there was no rigor in the establishment of methodologies, basically two forms of preparation: one considered formal according to the proposed curriculum and another informal, developed in the student's workplace ${ }^{(37)}$.

Nursing emerged with the objective of responding to the demands characterized by the health movement, and psychiatry care was not identified as a public health problem ${ }^{(10)}$. The perspective of psychic suffering was permeated with prejudices and stigmas that came from all sectors of society, and the teaching of psychiatric nursing was responsible for creating control agents who acted as helpers in the fight against evil that was limited to behavior outside of standard ${ }^{(5,10)}$. The discipline'Nurse Art in Nervous and Mental Disorders' of the DNSP school was in the curriculum with small hours ${ }^{(10,16,28-29,37)}$. However, it is stated that the discipline was not even given because they thought it was harmful to the students. Only from 1935 did psychiatric nursing education become a compulsory subject, using minimal scientific knowledge to care for the mentally ill ${ }^{(12,28-29,37)}$.

As far as the profile or expected competences of the student, from 1930 the contents deal with clinical aspects of the mental illness with a biologicist practice of hospital performance ${ }^{(13,30)}$. The teaching of pathologies and syndromes was given by the psychiatrist ${ }^{(29)}$. In this first moment of formalization of nursing education, the contents were limited to signs and symptoms and definitions of pathological charts ${ }^{(29,35,37-38)}$. These characteristics in the teaching 
are due to the historical context in which nursing submerges in the scientific universe, refuting that this teaching based on clinical aspects is the result of a context of positivist ideals to science ${ }^{(38)}$.

The biomedical model arises anchored in the positivist philosophy, adhering to health a logic of searches for absolute truths, leading to the fragmentation of the body in different systems that are interrelated. Published in 1996, the article 'Pesquisa em enfermagem e o positivismo' ${ }^{\prime(40)}$ reports that the influence of positivist thinking in nursing has existed since the beginnings of modern nursing. According to the author, Florence Nightingale motivations, being faith and religion, converged with positivist thinking, by making feasible the construction of a nursing that walks towards progress, as a science of care ${ }^{(13)}$.

\section{Psychiatric nursing and mental health teaching: the 1949 curriculum}

In 1949 Law 775, which formalized the duration of the nursing course in 36 months and that of the nursing assistant in 18 months. This Law also made compulsory the teaching of psychiatric nursing. In addition, art. 5 of Decree 27.426 describes the contents that would become compulsory in nursing teaching. The list of the contents of psychology in the first series of the course and the discipline of nursing and psychology neurological and psychiatric, in the second ${ }^{(9-10,13,15-16,29,33,35)}$. Art. 6 of the same Decree established the obligation of practical teaching instructing the urgency to include practical classes for each of the fields of nursing. However, even with this requirement, there were few practical lessons and, when they did, the places were not conducive to learning, because they were unhealthy and precarious ${ }^{(10,13,29,33)}$.

At the time, it was necessary to prepare professionals to work in this care field, due to the need to make nursing a profession whose competence to cover the various areas where care is necessary ${ }^{(9)}$. These needs motivated the expansion of the nursing field, increasing profession prestige, since the officialization of institutional political projects allowed the inclusion of nursing in the field of psychiatry ${ }^{(29)}$. The content of teaching in this period was little different from the curriculum established in 1923, restricted to the biological perspective, whose psychiatric care was exclusively focused on a hospital context. Emphasis was given to the clinical aspects of mental illness, insisting on annulling the individualities of each human being. In this respect, an exercise is emphasized to classify and catalog similarities, in order to establish common care actions for all people ${ }^{(5,10,13,30,35)}$.

In the 1950s, Brazilian universities included Psychoanalysis in the curriculum, although Freud's studies had already been referenced among Brazilian physicians and psychiatrists since the 19th century ${ }^{(41-42)}$. This and other psychological currents participated in the contents of psychiatric nursing teaching, with little influence, since care assistance and practice did not involve actions that valued psychological aspects of human behavior ${ }^{(13,30,35)}$. These new knowledge ended up in addition to those already established, maintaining the "organic basis of understanding mental illness within reason-effect rationality, proposing a new reading on mental disorders, which included a mind and its subjective components"(35).

The 1950s experienced the rise of the first theorists of psychiatric nursing ${ }^{(43)}$. Hildegard Peplau is mentioned as a consolidator of the therapeutic relationship, with the Theory of Interpersonal Relations ${ }^{(28,32)}$, considered the first instrument of systematization in nursing performed by a nurse. Travelbee and Minzoni are also mentioned at the time, describing the praxis of psychiatric nursing based on the interpersonal process ${ }^{(28)}$. The teaching methodology describes the traditional model of education, being not flexible, aiming at transferring knowledge from professor to student ${ }^{(10)}$.

\section{Psychiatric nursing and mental health teaching: the 1962 curriculum}

On October 19, 1962, the Federal Education Council issued Opinion 271 that allowed a new moment in nursing teaching in Brazil, bringing measures such as the division of teaching in the general course and specializations in Obstetrics and Public Health, in addition to reducing practical classes and increasing theoretical ${ }^{(15)}$. This curriculum proposal privileged the curative area aiming to train professionals to work in specialized clinics and hospitals, making optional the disciplines focused on public health and reinforcing the pedagogical model of specialized clinics. It also sought to standardize nursing education, establishing a minimum compulsory curriculum that served as a guide for other schools to organize their courses.

In this context, the Brazilian preventive psychiatry movement, or the 'new psychiatry' ${ }^{\prime(9,13,15,30,33)}$, which added to the teaching of psychiatric nursing contents that address notions of drugs and mental disorders with the topics 'family and nursing therapy' as a basis in the therapeutic relationship ${ }^{(10)}$. Preventive psychiatry was also responsible for including in teaching contents about nursing care in the use of psychotropic drugs and their disorders, and aspects of personality development. The principles of the therapeutic community are approached as being anchored to those of preventive psychiatry ${ }^{(10,13,15,21,33)}$.

Establishing a new model of psychiatric nursing in a hospital emerged under the influence of "new psychiatry aimed at transforming hospitals from mental illness into centers of healing and recovery"(9). For this change to occur, a renewal of health was required, both in the workforce and in the structure, and it was necessary to train new mental health workers, with the aim of "broadening the concept of health/mental illness process, in order to both prophylactic and therapeutic aspects"(9).

It was noticed that nursing had the opportunity to abandon practices that did not correspond to professional care and to establish a leading role in the changes in mental health care. Indispensability of a professor and nurse specialized in psychiatric nursing in the nursing department of the Institute of Psychiatry of Universidade Federal do Rio de Janeiro. Thus, the work of nursing is directed at the conceptions of the new psychiatry, impelling this movement of construction of a new psychiatric nursing ${ }^{(9)}$.

In teaching, changes occurred little influenced the practices that were maintained in psychiatric hospitals, and the workload remained mostly centered on organic and biological content. According to this perspective, the teaching of psychiatric nursing was shaped according to the economic interests of the time ${ }^{(6,15)}$. Hospitals and outpatient clinics were places of practical classes $^{(9,13,15,21)}$. In the perspective of preventive psychiatry, we observe the timid and unprecedented inclusion of outpatient clinics as a field of practice. They were used as field to observe 
patients and their symptoms $\mathrm{s}^{(15)}$. There is persistent concentration of stages in hospitals ${ }^{(30,33)}$, and the methodological model of teaching is described as traditional $\left.\right|^{(7,10)}$.

It is observed that a description appears in which the future nurse should know "to deal with emotions, to evaluate human behaviors and to plan appropriate care to each situation"(9). Thus, when analyzing the findings of this period, there is a singularity to the others, presenting in a pioneering way a simple, unprecedented description of the student's expected abilities.

\section{Psychiatric nursing and mental health teaching: the 1972 curriculum}

Although the 1970s were the scene of several political and socioeconomic changes in the country, there were no direct interference from the Military Dictatorship in psychiatric nursing education. However, the ideals of Psychiatric Reform in Italy in the period led to the Brazilian Psychiatric Reform ${ }^{(12)}$. Opinion 163 of 1972, which is responsible for the formalization of a new curriculum, refers to the influence of the Brazilian Nursing Association (ABEn - Associação Brasileira de Enfermagem), in order to value the importance of quality of care ${ }^{(16,24)}$.

After the military coup in 1964 in Brazil, government reforms instituted promoted the growth of the private-profit health system, favoring a hospitable hospital structure. Consequently, faced with the precarious conditions of life, a large part of the population suffers significant health problems. Negligence in this context has caused popular dissatisfaction that culminated in the Health Reform, whose principles were consolidated at the $8^{\text {th }}$ Brazilian National Conference on Health in $1986^{(10)}$.

During this period, the Mental Health Workers Movement (MTSM - Movimento dos Trabalhadores em Saúde Mental) emerged, promoted by the dissatisfaction of professionals ${ }^{(44)}$, who had influence of the psychiatric reform in Italy, which aimed at improving psychiatric care with deinstitutionalization ${ }^{(12,28)}$. In 1987 the $2^{\text {nd }}$ Congress of Mental Health Workers and the $1^{\text {st }}$ Brazilian National Conference on Mental Health took place, which were settings that precipitated the discussion about Psychiatric Reform in Brazil, with harsh criticism of the current asylum model ${ }^{(15)}$.

The teaching of psychiatric nursing advanced considerably in the period in search of a new model, with the incorporation of educational, preventive and therapeutic practices with humanized approach and comprehensive care for the patient, seeking to take into account the citizenship of the subjects and prioritizing extra hospital health care spaces ${ }^{(12,15-16,20)}$. We began to look at disease treatment, conditions and biopsychosocial needs of patient, and importance of therapeutic relationship and community actions ${ }^{(10,22)}$.

Although this period has contributed positively to psychiatric nursing, nursing and nursing education teaching still maintain practices of organic medicine, with total dissociation to new conceptions of health-disease. It should be emphasized that the health, psychiatric and curriculum movements were fundamental to highlight the needs and gaps in nursing care and teaching, opening the way for the establishment of new discussions ${ }^{(27)}$. Psychiatric nursing established itself with the same relevance as the other training disciplines, although there was resistance on the part of professors, blocking the rise of new practices ${ }^{(24)}$.
With regard to places of practice, training continues to take place predominantly in psychiatric hospitals and alone in outpatient clinics. There were already incipient questions from some professors about the possibility of providing mental health care without isolation of the individual from their family and from their own environment ${ }^{(13,20,26,28,33)}$. Regarding the contents, the discipline of psychiatric nursing prioritized the study of psychopathologies with a focus on normal and pathological, maintaining a stigmatizing practice ${ }^{(6,13,17,30,39)}$. There is presence of preventive psychiatry, psychoanalysis and psychodynamic discourses in the contents, but the focus on teaching remained in the psychiatric clinic, maintaining the traditional practices ${ }^{(13,33,39)}$.

Regarding the methodology of teaching in this period, this time the student's expected abilities indicate that "the tendency to make the nurse a generalist should extend also to the student who underwent the discipline of psychiatric nursing"(16). It is understood as important to allow the student expressive emotions and feelings, with the purpose of providing a space for him to work his personality and training ${ }^{(17,20)}$ and that seeks to reflect on the difficulties encountered by students in the discipline of psychiatric nursing ${ }^{(20,30,33)}$. Despite the important advances, the traditional model of education still allowed little flexibility of the curricula, limiting the possibility of critical-reflexive formation of future nursing professionals ${ }^{(10)}$.

\section{Psychiatric nursing and mental health teaching: the 1994 curriculum}

In December 1994, Ordinance 1,721 was created bringing changes in the structure of nursing curriculum. The minimum workload of 3,500 total hours for undergraduate nursing courses was established. The courses, in general, began to be organized in thematic areas, such as biological and social bases of nursing; fundamentals of nursing; nursing assistances and nursing administration ${ }^{(8)}$. This phase erupted as a result of the movements stemming from the struggles and achievements of sanitary reform and Psychiatric Reform that had been "screaming" for decades, as mentioned in the discussion of the 1972 curriculum ${ }^{(8,10)}$.

From this curriculum, the concepts of normal and pathological were integrated into the concepts of health-disease "having as a reference the idealism of normality, of balance, and deviations considered pathological"(33). Still, some authors considered that there were few changes, and the foundations of the asylum care model were still maintained in care for person in psychological distress ${ }^{(35,37)}$. It was found as a description of the fields of practice: psychiatric hospitals $\mathrm{s}^{(30-31,35)}$; mental health outpatient clinic $^{(10,15,30-31)}$; psychiatric emergencies ${ }^{(10,31)}$; general hospital ${ }^{(10,15,30-31)}$; psychiatric clinic $^{(31)}$; and day hospital ${ }^{(10,35)}$. Support houses, basic health units, sheltered pensions, community centers, housing for residents, Psychosocial Care Nucleus (NAPS - Núcleo de Atenção Psicossocial), Psychosocial Care Center (CAPS - Centro de Atenção Psicossocial), expression workshops and literacy services were also cited ${ }^{(10)}$.

The contents of the lesson were still based on the study of psychopathologies with practices focused on the disease, madness and stigmatization of the mentally ill, with no perspective of including this individual in the social context ${ }^{(6,15,30,35)}$. The teaching-learning process of the therapeutic relationship, although explained in theory, has no applicability in the fields of practice when these 
consist of psychiatric hospitals, preventing learning from happening $^{(10)}$. Other contents covered in the period consist of the study of the patient's control and protection ${ }^{(35)}$, dependence on alcohol and other drugs ${ }^{(31)}$ and therapeutic methods of intervention in the disease ${ }^{(30)}$. Emerging, for the first time in the studies, bibliographies of more critical approaches to mental illness processes ${ }^{(35)}$.

The teaching methodologies in this period criticize the reproduction of fragmentation of contents and teaching trends in directing the teaching to the performance in the psychiatric institution, reinforcing the knowledge and practices of exclusion ${ }^{(30-31,35)}$. For the first time, it is mentioned that, at the option of the professors, in some institutions, the problem-solving methodology is already used $^{(10,34)}$. Other studies point out that teaching in the period still emphasizes a more biological perspective, pointing out that teaching aims to enable the student to recognize symptoms ${ }^{(30-31)}$.

\section{Psychiatric nursing and mental health teaching: the 2001 curriculum}

The year 2001 was the Resolution CNE/CES n.3, which instituted the Brazilian National Curriculum Guidelines of the Undergraduate Nursing Course (DNN/ENF - Diretrizes Curriculares Nacionais do Curso de Graduação em Enfermagem) ${ }^{(45)}$, which brought the generalist, humanistic, critical and reflexive formation. In this curriculum, the consolidation of the diverse needs that were being claimed in nursing care and training ${ }^{(1)}$. In the same year, the Psychiatric Reform Law was signed, which reviews assistance in the field of mental health by returning it primarily to the primary health care network and introduces mechanisms of protection and rights for people with mental disorders ${ }^{(28)}$.

The theoretical bases for the teaching of nursing care begin to seek to strengthen the person-person relationship and the Human Needs Theory, and the systematization of care as a possibility to develop care is also pointed out. Training remains generalist and focuses on primary mental health care ${ }^{(23,28)}$. This curriculum change is also due to the fact that the Psychiatric Reform required a nurse trained to act in a community model, inclined towards psychosocial rehabilitation, recognition of life and health as a fundamental right and prepared for comprehensive care ${ }^{(8,13)}$.

In the period, care in psychiatric nursing began to be centered on the model of psychosocial care, seeking to lateralize the pathology ${ }^{(5,12-13)}$. There was discussion on the need for "social inclusion, patient autonomy and citizenship, humanism, interpersonal and therapeutic relationship, and multidisciplinary teamwork"(12). However, there are considerations regarding the difficulty of training for psychosocial care ${ }^{(22)}$. In the same sense, professors are expected to provide the students with devices that enable the development of creativity, therapeutic communication, empathy and interpersonal relationship with the patient, team, family and community ${ }^{(13,46)}$.

Nonetheless, training institutions that adopt the biomedical model of mental health care are revealed, contrary to SUS premises $^{(12,14)}$. Psychiatric Reform has designated a new mode of care that, while adequate in the theoretical perspective, has resulted in the need to qualify professionals and professors to know public policies and new perspectives of care ${ }^{(11,19)}$. The situation demands from schools and professors "a replanning of their theoretical-practical activities involving the teaching of nursing care from the perspective of the psychosocial paradigm ${ }^{\prime \prime(19)}$. There are difficulties in implementing this proposal because there is resistance on the part of professors and students, as changes in behavior and attitudes of both are required ${ }^{(24-25)}$.

In this curriculum, the places of practice indicated are the most varied: psychiatric hospital ${ }^{(5,14,19,32)}$, territorial health service ${ }^{(5-6)}$, Psychosocial care Center ${ }^{(5,8,11-12,19,25,32,39)}$, hospital ${ }^{(6,10,18-19,25,32)}$, primary $\operatorname{care}^{(8,19,23,25-26,32,34,36)}$, therapeutic residences ${ }^{(12,25)}$, help groups ${ }^{(18-19)}$, schools $^{(18-19)}$, outpatient clinics ${ }^{(19,32,39)}$, Family Health Support Centers ${ }^{(25)}$, day hospital (32,39) and chemical dependency rehabilitation center ${ }^{(32)}$.

It is observed evolution as to varieties and distancing of the hospital-centered tendency, if there is comparison of the fields offered in the Curriculum Reform of 1972 and previous decades, although it is questionable that the presence of the psychiatric hospital still exists as a field, despite the content of the legislation in force in the time. The disruption of this model is considered complex because it is a paradigm break established over many years, as well as presupposes the construction of new models of care ${ }^{(47)}$.

In many courses, mental health content becomes cross-sectional in training, being referenced in varied contexts and conditions. However, the contents of psychopathology and major psychiatric disorders, the psychosocial care clinic, the Public Mental Health Policy under the prism of Psychiatric Reform and the approach to the fight against social exclusion, are protected for the discipline of psychiatric nursing ${ }^{(12)}$. It is observed that the contents therapeutic communication and therapeutic relationship are highlighted in the teaching in this period. In addition, there is less emphasis on psychiatric disorders, and this content was once prominent, reduced to the study of common mental disorders. There is a single reference to health-mental illness process, promotion in mental health, concept of madness, Psychiatric Reform and Psychosocial Care Model ${ }^{(5,12,30)}$.

There are already several references pointing to the presence of active methodologies in teaching, such as teaching-learning strategies $^{(6,19,25,34)}$. There are also considerations about the difficulty of training professionals for psychosocial care advocated with a traditional approach ${ }^{(6)}$, although there are indications that traditional and technical pedagogical approaches to nursing education in mental health are still used ${ }^{(22)}$ and reflections that teaching methods need to be reviewed ${ }^{(23)}$. In this scope, the use of the methodology of problem-based learning ${ }^{(32)}$, possibilities of approach for the development of skills ${ }^{(22)}$, use of other innovative strategies such as lectures, experiences, integrated panel, interviews, dramatizations, reading texts and discussions in groups ${ }^{(39)}$. Emphasis is placed on the importance of the student if he constitutes as an active agent in the teaching learning process ${ }^{(25,34,48)}$.

With regard to the expected competences, it is understood that in order for the student to develop a therapeutic relationship in mental health, some competences are needed which are "difficult to develop because they call for a personal, ethical and moral development that goes hand in hand of human growth"(7), reinforcing the need for the development of skills to be cross-sectional. It is understood that nursing courses have opportunized the resignification of madness, suppressing stigmas and prejudices ${ }^{(12)}$. Furthermore, there is a description that communication, security and self-knowledge ${ }^{(25)}$, the need to train professionals committed to citizenship, and the quality of life of the psychic suffering person ${ }^{(27,49)}$ are expected student skills.

Finally, the Chart 2 summarizes the results according to the year of the curriculum and the dimensions of analysis: 
Chart 2 - Synthesis of results according to curriculum year and analysis dimensions

\begin{tabular}{|c|c|c|c|c|}
\hline Curriculum & Thinking model & Practice places & Methods or contente used & Profile or professor competence \\
\hline 1923 & $\begin{array}{l}\text { Nightingale model; Positivist } \\
\text { currents; Biomedical model }\end{array}$ & Psychiatric hospital & $\begin{array}{l}\text { Traditional teaching model; } \\
\text { Minimum scientific knowledge to } \\
\text { care for the mentally ill }\end{array}$ & $\begin{array}{l}\text { Assisting the physician in } \\
\text { psychiatric procedures; guarding } \\
\text { the patient's physical needs }\end{array}$ \\
\hline 1949 & $\begin{array}{l}\text { Organic model; } \\
\text { Positivist currents; Theorists } \\
\text { Peplau, Travelbee and } \\
\text { Minzoni }\end{array}$ & Psychiatric hospital & $\begin{array}{l}\text { Traditional teaching model; } \\
\text { Emphasis on clinical aspects; } \\
\text { Insertion of Freudian Psychoanalysis; } \\
\text { Interpersonal relationships }\end{array}$ & $\begin{array}{l}\text { Establishing care for people } \\
\text { including those with mental illness }\end{array}$ \\
\hline 1962 & $\begin{array}{l}\text { Preventive Psychiatry; } \\
\text { Psychiatric Nursing; } \\
\text { Theorists Peplau, Travelbee } \\
\text { and Minzoni }\end{array}$ & $\begin{array}{l}\text { Psychiatric hospital, } \\
\text { outpatient clinic and } \\
\text { community }\end{array}$ & $\begin{array}{l}\text { Traditional teaching model; Organic } \\
\text { contents; Integration between } \\
\text { theoretical and practical teaching in } \\
\text { minimum curriculum }\end{array}$ & $\begin{array}{l}\text { The nurse must deal with human } \\
\text { emotions and behaviors and plan } \\
\text { care }\end{array}$ \\
\hline 1972 & $\begin{array}{l}\text { Psychiatric Reform; } \\
\text { Democratic Psychiatry; } \\
\text { Theorists Peplau, Travelbee } \\
\text { and Minzoni }\end{array}$ & $\begin{array}{l}\text { Psychiatric hospital, } \\
\text { outpatient clinic and } \\
\text { community }\end{array}$ & $\begin{array}{l}\text { Therapeutic relationships } \\
\text { and community actions; } \\
\text { Psychopathology; Psychiatric clinic }\end{array}$ & $\begin{array}{l}\text { General nurse with knowledge of } \\
\text { Psychiatric Nursing }\end{array}$ \\
\hline 1994 & $\begin{array}{l}\text { Critical approaches to } \\
\text { health-mental illness process; } \\
\text { Theorists Peplau, Travelbee } \\
\text { and Minzoni }\end{array}$ & $\begin{array}{l}\text { Psychiatric Hospital, } \\
\text { outpatient clinic, } \\
\text { Nucleus and Center } \\
\text { for Psychosocial Care }\end{array}$ & $\begin{array}{l}\text { Methodology of problematization } \\
\text { with biologicist perspective }\end{array}$ & $\begin{array}{l}\text { Nurse with critical training and } \\
\text { symptom recognition }\end{array}$ \\
\hline 2001 & $\begin{array}{l}\text { Psychiatric Model; } \\
\text { Psychosocial Care Model }\end{array}$ & $\begin{array}{l}\text { Psychosocial Care } \\
\text { Network }\end{array}$ & $\begin{array}{l}\text { Traditional and problematizing } \\
\text { methodologies; therapeutic } \\
\text { relationship, longitudinal care }\end{array}$ & $\begin{array}{l}\text { General, humanistic, critical and } \\
\text { reflexive formation }\end{array}$ \\
\hline
\end{tabular}

\section{Study limitations}

The limitations are related to the difficulty of discussing the topic in depth, given the fact that it is a historical review, without a temporal cut, that seeks to reveal aspects of nursing curriculum inserted since the 1920s, with few publications certain periods. Moreover, exclusion of incomplete articles or the possibility of not including articles that deal with the subject are limitations, since they may not have been curtailed by the search terms, being the study's potential weaknesses.

\section{Contributions to Nursing, Health or Public Policy}

This study made it possible to observe the historical evolution of psychiatric nursing and mental health teaching. The theme allowed clarified observation that the needs claimed by society, as a right to health, will allow public policies materialization responding to divergent historical contexts. Thus, it was evidenced the need to observe society's yearnings, when rethinking the nursing undergraduate teaching, training nurses that meet the mental health needs consistent with the social reality.

\section{FINAL CONSIDERATIONS}

Curriculum change carries forces correlation, since their origin comes from a field of disputes in which education can have the purpose of training for a certain political-ideological model or of emancipation in a critical and transformative model.

Determinants for the transformation of psychiatric nursing and mental health teaching involved curriculum changes, Psychiatric Reform, and the way nursing undergraduate courses and schools take these determinants. Its influence in health nursing teaching has more to do with general aspects and how each professor uses the current curriculum and its relation with the teaching of the specific area.

Finally, the data showed that the different nursing curriculum reflect the conflict of interests and the impact on mental health education, requiring professors mobilized through entities such as $A B E n$ to indicate the need or not of Curriculum Reform and the impact that is aimed.

\section{REFERENCES}

1. Duarte APRS, Vasconcelos M, Silva SV. A trajetória curricular da graduação em enfermagem no Brasil. REID [Internet]. 2016 [cited 2017 Aug 30];1(7):50-63. Available from: http://reid.ucm.ac.mz/index.php/reid/article/view/120

2. Pessoa Jr JM, Santos RCA, Clementino FS, Nascimento EGC, Miranda FAN. Mental health education and professional practice in the psychiatric hospital. Texto Contexto Enferm. 2016;25(3):e3020015. doi: 10.1590/0104-07072016003020015

3. Ganong LH. Integrative reviews of nursing. Res Nurs Health. 1987; 10(1): 1-11.

4. Minayo MCS. O desafio do conhecimento. 14a ed. São Paulo: Hucitec; 2014.

5. Cortes JM, Kantorski LP, Barros S, Antonacci MH, Chiavagatti FG, Willrich JQ. Saberes e fazeres que integram o ensino de enfermagem psiquiátrica na perspectiva de enfermeiros docentes. Rev Port Enfermagem Saúde Ment [Internet]. 2014 [cited 2017 Mar 10];12:34-42. 
Available from: http://www.scielo.mec.pt/scielo.php?script=sci_arttext\&pid=S1647-21602014000300005

6. Aragão MN, Soares IG. (Trans)formando e ousando o método de ensino de enfermagem no cuidado à saúde mental. Rev Port Enferm Saúde Ment [Internet]. 2014 [cited 2017 Mar 10]; 12: 59-64. Available from: http://www.scielo.mec.pt/scielo.php?script=sci_arttext\&pid $=$ S1647-21602014000300008

7. Martinho J, Pires R, Carvalho JC, Pimenta G. Formação e desenvolvimento de competências de estudantes de enfermagem em contexto de ensino clínico em saúde mental e psiquiatria. Rev Port Enferm Saúde Ment [Internet]. 2014 [cited 2017 Mar 10];1:97-102. Available from: http://www.scielo.mec.pt/scielo.php?script=sci_abstract\&pid=S1647-21602014000100016\&lng=pt\&nrm=iso

8. Neves HG, Lucchese R, Munari DB. Saúde mental na atenção primária: necessária constituição de competências. Rev Bras Enferm. 2010;63(4):666-70. doi: 10.1590/S0034-71672010000400025

9. Peres MAA, Barreira IA. Uma nova enfermagem psiquiátrica na universidade do Brasil nos anos 60 do século XX. Esc Anna Nery. 2008;12(1):108-14. doi: 10.1590/S1414-81452008000100017

10. Barros S, Lucchese R. Problematizando o processo ensino-aprendizagem em enfermagem em saúde mental. Trab Educ Saúde. 2006;4(2):337-54. doi: 10.1590/S1981-77462006000200007

11. Tavares CMM. A interdisciplinaridade como requisito para a formação da enfermeira psiquiátrica na perspectiva da atenção psicossocial. Texto Contexto Enferm. 2005;14(3);403-10. doi: 10.1590/S0104-07072005000300012

12. Magnago C, Tavares CMM. O ensino de enfermagem psiquiátrica nas Universidades Públicas do Estado do Rio de Janeiro. Rev Elet Enf. 2012;14(1):50-8. doi: 10.5216/ree.v14i1.10626

13. Kantorski LP. A brief history of psychiatric nursing teaching in Brazil. Nurse Educ Pract. 2005;5(1):58-60. doi: 10.1016/j.nepr.2004.10.002

14. Silva ATM, Souza JS, Silva CC, Nóbrega MML, Filha MO, Barros S, Braga JE. Formação de Enfermeiros na perspectiva da Reforma Psiquiátrica. Rev Bras Enferm. 2004;57(6):675-78. doi: 10.1590/S0034-71672004000600008

15. Olschowsky A, Barros S. Graduação em enfermagem: aprendendo a aprender a reforma psiquiátrica brasileira. Rev Esc Enferm USP. 1999;33(4):377-83. doi: 10.1590/S0080-62341999000400009

16. Gross HB, Casagrande LDR. Enfermagem psiquiátrica como disciplina de graduação em no Brasil: uma visão de conjunto. Rev Esc Enferm USP [Internet]. 1987 [cited 2017 Mar 10]; 21(3):225-34. Available from: https://www.revistas.usp.br/reeusp/article/download/135894/131710

17. Gross HB, Casagrande LDR. Plano de ensino para a disciplina de enfermagem psiquiátrica. Rev Gaúcha Enferm [Internet]. 1984 [cited 2017 Mar 10];5(2):245-60. Available from: http://seer.ufrgs.br/index.php/RevistaGauchadeEnfermagem/article/view/3271/43248

18. Villela JC, Maftum MA, Paes MR. The teaching of mental health in a nursing undergraduate curse: a case study. Texto Contexto Enferm. 2013;22(2):397-406. doi: 10.1590/S0104-07072013000200016

19. Rodrigues J, Santos SMA, Spricigo JS. Teaching nursing care in mental health in undergraduate nursing. Acta Paul Enferm. 2012;25(6):84451. doi: 10.1590/S0103-21002012000600004

20. Fraga MNO, Damasceno RN, Calixto MLG. Ensino de relacionamento terapêutico em enfermagem psiquiátrica: dificuldades e perspectivas. Rev Bras Enferm. 1986;39(2):94-102. doi: 10.1590/S0034-71671986000300017

21. Fernandes DAB. Assistência psiquiátrica através da divisão de saúde mental e o ensino prático de enfermagem psiquiátrica. Rev Bras Enferm. 1968;20:545-56.

22. Lucchese R, Barros S. The constitution of competences in mental health nursing education and practice. Rev Esc Enferm USP. 2009;43(1):14653. doi: 10.1590/S0080-62342009000100020

23. Rodrigues J, Santos SMA, Spricigo JS. Teaching mental health nursing care through the faculty's discourse. Texto Contexto Enferm. 2012;21(3):616-24. doi: 10.1590/S0104-07072012000300017

24. Zem-Mascarenhas SH, Beretta MIR. Participando da construção de um projeto pedagógico da enfermagem. Rev Esc Enferm USP. 2005;39(4):437-42. doi: 10.1590/S0080-62342005000400010

25. Rodrigues J, Santos SMA, Zeferino MT, Tosoli M. Integrative review about the teaching of the nursing care in mental health. J Res Fundam Care Online. 2014;6(1):433-49. doi: 10.9789/2175-5361.2014.v6i1.433-449

26. Miyai FT, Barros S, Cortes JM. Nursing students and mental health education in primary care. Rev Gaúcha Enferm. 2014;35(1):94-101. doi: 10.1590/1983-1447.2014.01.37887

27. Fernandes JD, Sadigursky D, Silva RMO, Amorim AB, Teixeira GAS, Araújo MCF. Teaching psychiatric nursing/mental health: its interface with the Brazilian Psychiatric Reform and national curriculum guidelines. Rev Esc Enferm USP. 2009;43(4):955-60. doi: 10.1590/S0080-62342009000400031

28. Espiridião E, Silva NS, Caixeta CC, Rodrigues J. A Enfermagem Psiquiátrica, a ABEn e o Departamento Científico de Enfermagem Psiquiátrica e Saúde Mental: avanços e desafios. Rev Bras Enferm. 2013;66(spe):171-6. doi: 10.1590/S0034-71672013000700022

29. Silva Júnior OC, Moreira A, Amorim W, Porto F. A enfermagem psiquiátrica e a enfermagem moderna no Rio de Janeiro: uma lição da história. Rev Bras Enferm. 2001;54(2):229-36. 10.1590/S0034-71672001000200008

30. Kantorski LP, Silva GB, Silva ENF. The conceptions and scenarios of the teaching of psychiatric nursing and mental health. Rev Bras Enferm. 2001;54(3):409-19. doi: 10.1590/S0034-71672001000300003

31. Kantorski LP, Silva GB. O ensino de Saúde Mental e Enfermagem Psiquiátrica: um olhar a partir dos programas das disciplinas. Rev Latino-Am Enfermagem. 2000;8(6):27-34. doi: 10.1590/S0104-11692000000600005 
32. Kantorski LP, Pinho LB, Saeki T, Mello e Souza MCB. Relacionamento terapêutico e ensino de enfermagem psiquiátrica e saúde mental: tendências no Estado de São Paulo. Rev Esc Enferm USP. 2005;39(3):317-24. doi: 10.1590/S0080-62342005000300010

33. Kantorski LP, Silva GB. Um objeto de estudo sobre ensino de enfermagem psiquiátrica e saúde mental. Rev Bras Enferm. 1998;51(3):417-30. doi: 10.1590/S0034-71671998000300007

34. Siqueira Júnior AC, Otani MAP. The teaching of psychiatric nursing and mental health in the curriculum by competence. REME - Rev Min Enferm. 2011;15(4):539-45. doi: S1415-27622011000400010

35. Braga VAB, Silva GB. O ensino de enfermagem psiquiátrica no Ceará: a realidade que se esboça. Rev Latino-Am Enfermagem. 2000;8(1):1321. doi: 10.1590/S0104-11692000000100003

36. Albuquerque VS, Campos JCL. Saúde mental no currículo integrado do curso de enfermagem do unifeso: diversificação de cenários e de estratégias de ensino-aprendizagem. Rev Pesqui Cuid Fundam Online. 2010;2(4):1516-27. doi: 10.9789/2175-5361.2010.v2i4.\%25p

37. Kirschbaun DIR. Análise histórica das práticas de enfermagem no campo da assistência psiquiátrica no Brasil, no período compreendido entre as décadas de 20 e 50. Rev Latino-Am. Enfermagem. 1997;5(spe):19-30. doi: 10.1590/S0104-11691997000500003

38. Silva TC, Vianna PCM, Silveira MR. O tempo: uma questão no ensino da enfermagem psiquiátrica. REME - Rev Min Enferm. 2007;11(3):32330. doi: S1415-27622007000300018

39. Munari DB, Godoy MTH, Espiridião E. Ensino de enfermagem psiquiátrica/saúde mental na Faculdade de Enfermagem da Universidade Federal de Goiás. Esc Anna Nery. 2006;10(4):684-93. doi: 10.1590/S1414-81452006000400010

40. Almeida AM, Oliveira ERA, Garcia TR. Pesquisa em enfermagem e o positivismo. Rev Esc Enf USP. 1996;30(1):25-32. doi: 10.1590/ S0080-62341996000100003

41. Kurimoto TCS, Penna CMM, Nitkin DIRK. Knowledge and practice in mental health nursing care. Rev Bras Enferm [Internet]. 2017;70(5):973-80. [Thematic Edition "Good practices and fundamentals of Nursing work in the construction of a democratic society"] doi: 10.1590/0034-7167-2016-0343

42. Coutinho DMB, Mattos AS, Monteiro CFD, Virgens PA, Almeida Filho NM. Ensino da psicanálise na universidade brasileira: retorno à proposta freudiana. Arq Bras Psicol [Internet]. 2013 [cited 2018 Mar 15];65(1):103-20. Available from: http://pepsic.bvsalud.org/scielo. php?script=sci_arttext\&pid=S1809-52672013000100008

43. Garcia APRF, Freitas MIP, Lamas JLT, Toledo VP. Nursing process in mental health: na integrative literature review. Rev Bras Enferm [Internet]. 2017;70(1):209-18. doi: 10.1590/0034-7167-2016-0031

44. Maftum MA, Pagliace AGS, Borba LO, Brusamarello T, Czarnobay J. Changes in professional practice in the mental health area against brazilian psychiatric reform in the vision of the nursing team. J Res Fundam Care Online. 2017;9(2):309-14. doi: 10.9789/2175-5361.2017. v9i2.309-314

45. Ministério da Educação (BR). Conselho Nacional da Educação (CNE). Resolução CNE/CES n 3, de 7 de novembro de 2001. Institui as Diretrizes Curriculares Nacionais do curso de graduação em Enfermagem [Internet]. Brasília: Ministério da Educação; 2001 [cited 2018 Mar 15]. Available from: http://portal.mec.gov.br/cne/arquivos/pdf/CES03.pdf

46. Azevedo AL, Araújo STC, Pessoa Júnior JM, Silva J, Santos BTU, Bastos SSF. Communication of nursing students in listening to patients in a psychiatric hospital. Esc Anna Nery. 2017;21(3):e20160325. doi: 10.1590/2177-9465-ean-2016-0325

47. Santos LM, Oliveira RMP, Dutra VFD, Porto IS. The process of knowledge transference: a matter concerning of teaching of psychiatric nursing Esc Anna Nery. 2017;21(3):e20160356. doi: 10.1590/2177-9465-ean-2016-0356

48. Higa EFR, Taipeiro EF, Carvalho MHR, Silva RHA, Tonhom SFR, Hafner MLBM. Avaliação do processo pedagógico em metodologia de aprendizagem ativa [Internet]. In: Atas do 5 Congresso Ibero-Americano em Investigação Qualitativa (CIAIQ). 2016 [cited 2017 Sept 06];1:270-8. Available from: http://proceedings.ciaiq.org/index.php/ciaiq2016/article/view/610/599

49. Costa TD, Gonçalves LC, Peixoto LS, Tavares CMM, Cortez EA. Contribuindo para a educação permanente na saúde mental. Persp Biol Saúde. 2017;23(7):9-15. doi: 10.25242/88687232017647 